JURNAL RESPIRASI

JR

Vol. 5 No. 2 Mei 2019

\title{
Penggunaan Extrafine Beclometason Diproprionat/Formoterol Fumarat pada PPOK
}

\author{
Sakinatus Syarifah ${ }^{1,2}$, Muhammad Amin ${ }^{2}$ \\ RS Anshari Saleh, Banjarmasin, Indonesia \\ Departemen Pulmonologi dan Ilmu Kedokteran Respirasi, Fakultas Kedokteran, Universitas Airlangga/RSUD Dr. Soetomo, \\ Surabaya, Indonesia
}

\begin{abstract}
Chronic obstructive pulmonary disease (COPD) is a condition characterised by poorly reversible airflow limitation that is generally progressive and causes serious disability. Exacerbations and co-morbidities contribute to the overall severity in individual patients. A fixed-dose inhaled corticosteroid/long-acting $\beta 2$-agonist (ICS/LABA) combination of extrafine beclometasone dipropionate and formoterol fumarate $(B D P / F F)$ has been recently approved for use in COPD. Small airway inflammation and remodelling are cardinal features of COPD; therefore, the ability of this extrafine formulation to reach the small, as well as the large, airways is likely to be therapeutically important by enabling treatment of inflammatory processes in the whole bronchial tree. The clinical development of extrafine BDP/FF has demonstrated significant benefits over extrafine FF in terms of lung function improvement and reduction of the exacerbation rate, thus supporting the beneficial effect of an ICS combined to a LABA in COPD patients. Head-to-head comparison studies versus other ICS/LABA combinations have shown that extrafine formulation enables clinical benefits to be achieved with a lower dose of ICS. Extrafine BDP/FF showed lung function and dyspneea improvements comparable to other ICS/LABAs, and a significantly faster onset of action was observed when compared with a salmeterol-containing fixed-dose combination.
\end{abstract}

Keywords: COPD, ICS/LABas/extrafine beclometasone dipropionate, formoterol fumarate

Correspondence: Sakinatus Syarifah, Departemen Pulmonologi dan Ilmu Kedokteran Respirasi, Fakultas Kedokteran, Universitas Airlangga/RSUD Dr. Soetomo . Jl. Mayjen Prof. Dr. Moestopo 6-8 Surabaya 60286. Email: sakinatuss@gmail.com

\section{PENDAHULUAN}

Penyakit paru obstruktif kronik (PPOK) merupakan penyakit yang dapat dicegah dan diobati, ditandai dengan hambatan aliran udara napas yang biasanya progresif dan berhubungan dengan respons inflamasi kronik di saluran napas dan paru terhadap partikel atau gas yang beracun/berbahaya. Eksaserbasi dan komorbid berkontribusi terhadap derajat berat penyakit. Progresif artinya penyakit ini berlangsung seumur hidup dan semakin memburuk secara lambat dari tahun ke tahun. PPOK merupakan salah satu penyakit tidak menular yang menjadi masalah kesehatan masyarakat di Indonesia. Data Badan Kesehatan Dunia (WHO) menunjukkan tahun 1990 PPOK menempati urutan ke-6 sebagai penyebab utama kematian di dunia, pada tahun 2002 menempati urutan ke-5, dan diperkirakan pada tahun 2030 akan menjadi penyebab kematian ke-3 di seluruh dunia setelah penyakit kardiovaskuler dan kanker. ${ }^{1}$ GOLD (Global Initiative for Obstructive Lung Disease) merekomendasikan bahwa penilaian keparahan penyakit harus multidimensi, yaitu dengan banyaknya gejala, tingkat keterbatasan aliran udara, dan risiko eksaserbasi. Penilaian keparahan PPOK dibagi ke dalam empat kategori (A, B, C, dan D). ${ }^{2}$ Terapi obat pilihan utama untuk pasien PPOK stabil adalah bronkodilator, dan pada pasien dengan risiko eksaserbasi kombinasi obat kortikosteroid inhalasi (ICS) dan long-acting $\beta 2$-agonis (LABA) direkomendasikan sebagai terapi pilihan.

Kombinasi LABA dengan ICS lebih efektif dibandingkan dengan komponen obat tunggal untuk meningkatkan fungsi paru, mengurangi eksaserbasi, dan meningkatkan status kesehatan umum pasien. $\beta$-agonis dan kortikosteroid memiliki target farmakologis yang berbeda dan beberapa interaksi yang bersinergis. ${ }^{3}$ Tinjauan kepustakaan ini membahas terapi pada PPOK, keunggulan terapi extrafine beclometason diproprionat/formoterol fumarat dibanding LABA/ICS lainnya, atau monoterapi pada PPOK. 


\section{Definisi PPOK}

PPOK adalah penyakit paru yang dapat dicegah dan diobati, ditandai dengan adanya keterbatasan aliran udara yang persisten dan umumnya bersifat progresif, berhubungan dengan respons inflamasi kronik yang berlebihan pada saluran napas dan parenkim paru akibat gas atau partikel berbahaya. Karakteristik hambatan aliran udara pada PPOK disebabkan oleh gabungan antara obstruksi saluran napas kecil (obstruksi bronkiolitis) dan kerusakan parenkim (emfisema) yang bervariasi pada setiap individu, akibat inflamasi kronik yang menyebabkan hilangnya hubungan alveoli dan saluran napas kecil dan penurunan elastisitas recoil paru. ${ }^{1,2}$

\section{Patogenesis PPOK}

Asap rokok dapat menyebabkan iritasi dan mengakibatkan infiltrasi pasa psaien PPOK. Hal ini terjadi karena adanya amplifikasi dari respon inflamasi. Faktor penyebab dari amplifikasi tersebut kemungkinan besar terjadi karena faktor genetik akan tetapi mekanismenya masih belum diketahui. Ornag bukan perokok juga dapat mengalami asma PPOK, namun respon inflamasi pada pasien tersebut sampai sekarang masih belum diketahui. Ada keadaan yang dapat memperberat inflamasi yaitu stres oksidatif dan proteinase. Kategori tersebut mengarah pada karakteristik perubahan patologis PPOK. $^{1}$ Adapun mekanisme inflamasi PPOK dapat dilihat pada gambar 1.

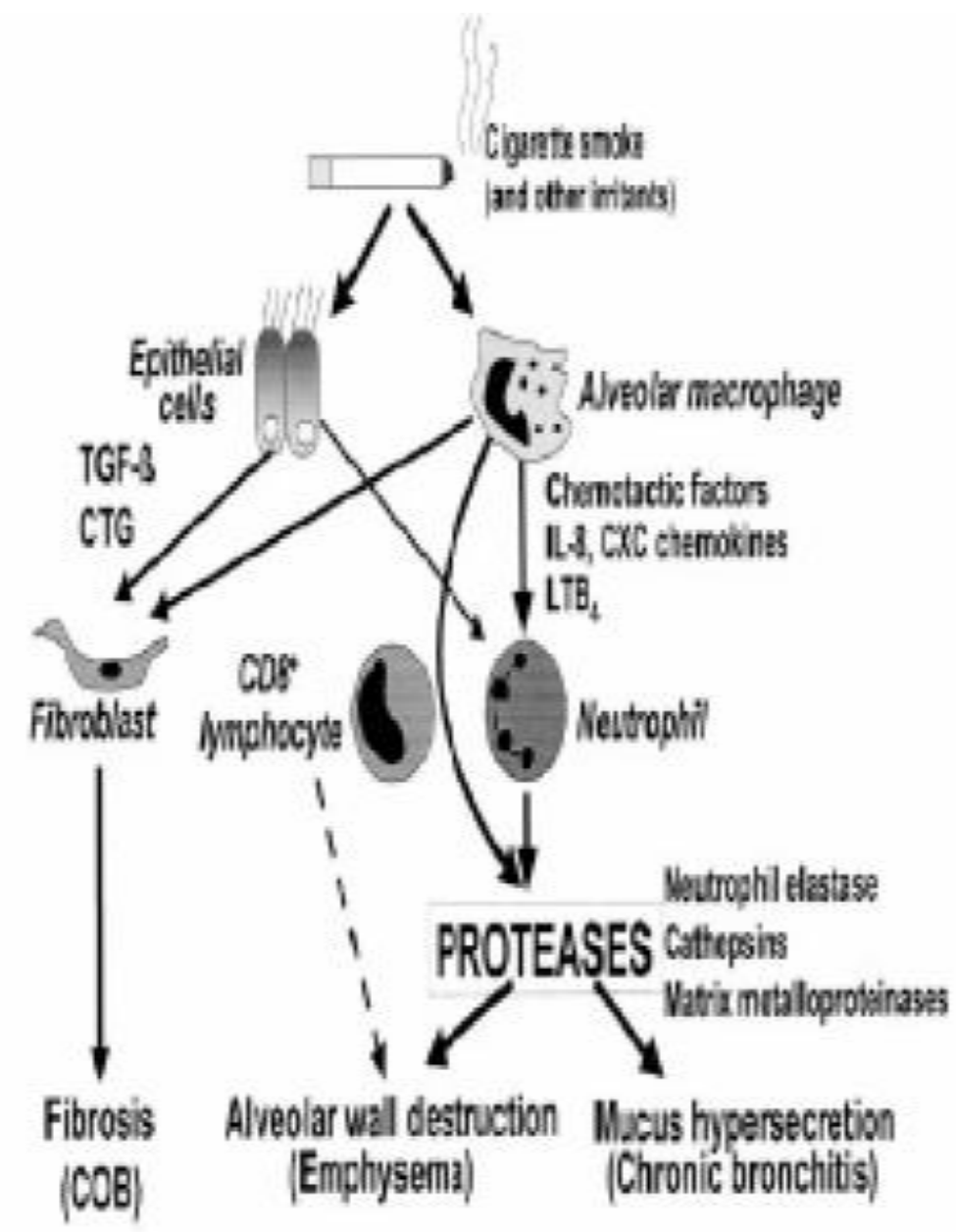

Gambar 1. Mekanisme inflamasi pada PPOK

Asap rokok (dan iritan lainnya) mengaktifkan makrofag di saluran pernapasan, melepaskan faktor kemotaktik neutrofil, termasuk IL-8 dan LTB4. Sel-sel ini kemudian melepaskan protease yang memecah jaringan ikat di parenkim paru, sehingga terjadi emfisema, dan juga merangsang hipersekresi mukus. Enzim ini biasanya dinetralkan oleh inhibitor protease, termasuk 1-antitrypsin,

SLPI, dan TIMP. Sel T sitotoksik (CD8) juga terlibat dalam kerusakan dinding alveolus. Fibroblas dapat diaktifkan oleh faktor pertumbuhan yang dirilis dari makrofag dan sel-sel epitel. CTG, connective tissue growth factor; $\mathrm{COB}$, chronic obstructive 


\section{Klasifikasi Pasien PPOK}

Pengelompokan pasien PPOK berdasarkan atas gejala, klasifikasi spirometri, dan faktor risiko (riwayat frekuensi eksaserbasi). Pengobatan pasien PPOK didasarkan pada pengelompokkan ini. Gejala diukur berdasarkan skor mMRC atau CAT. ${ }^{2}$

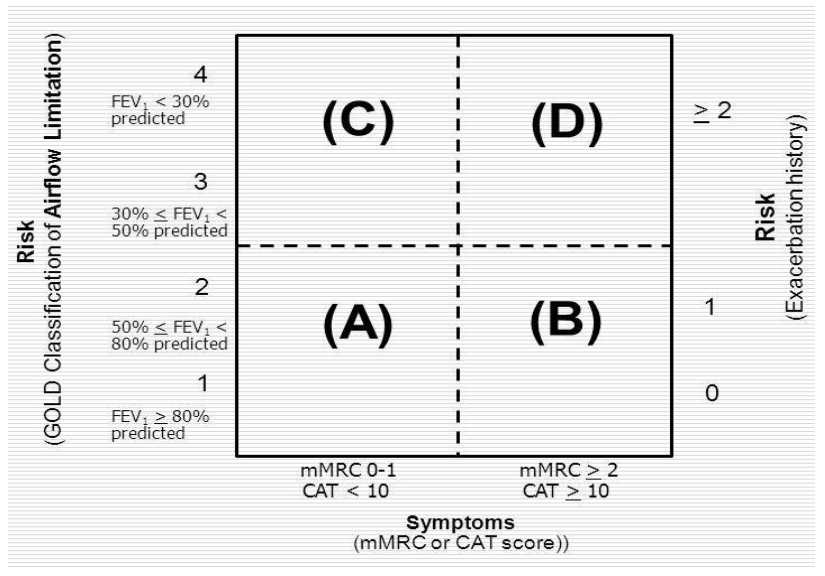

Gambar 2. Klasifikasi pasien $\mathrm{PPOK}^{2}$

\section{Penatalaksanaan PPOK}

PPOK merupakan penyakit paru kronik progresif dan tidak sepenuhnya reversibel, sehingga penatalaksanaan PPOK terbagi atas pelaksanaan pada keadaan stabil dan eksaserbasi akut. 1,2,4

1. Penatalaksanaan pada Keadaan Stabil

Kriteria PPOK stabil di antaranya adalah: 1) Tidak dalam kondisi gagal napas akut pada gagal napas kronik; 2) Dapat dalam kondisi gagal napas kronik stabil, yaitu hasil analisis gas darah menunjukkan $\mathrm{PH}$ normal, $\mathrm{PCO} 2>60 \mathrm{mmHg}$ dan PO2 < $60 \mathrm{mmHg}$; 3) Dahak tidak berwarna atau jernih; 4) Aktivitas terbatas tidak disertai sesak sesuai derajat berat PPOK (hasil spirometri); 5) Penggunaan bronkodilator sesuai rencana pengobatan, dan 6) Tidak ada penggunaan bronkodilator tambahan. ${ }^{2}$

Rekomendasi pengobatan PPOK versi GOLD sebelumnya didasarkan pada hasil spirometri saja. Namun, FEV1dinilai kurang dalam menilai status penyakit PPOK sehingga pengobatan untuk PPOK stabil harus mempertimbangkan keseluruhan gejala pasien individu dan risiko terjadinya eksaserbasi.

Tujuan penatalaksanaan pada keadaan stabil adalah sebagai berikut: ${ }^{5}$

a. Mengurangi gejala, dapat meningkatkan efektifitas latihan sehingga dapat dicapai status kesehatan dapat ditingkatkan.

b. Mengurangi risiko: mencegah progresivitas penyakit, mencegah eksaserbasi, mengurangi mortalitas.

Penatalaksanaan PPOK sebagai usaha evaluasi berkala dilakukan di poliklinik. Sedangkan untuk mempertahankan PPOK agar stabil dan mencegah eksaserbasi dapat dilakukan di rumah.

Penatalaksanaan di rumah:

Penatalaksanaan di rumah ditujukan bagi pasien PPOK berat yang harus menggunakan oksigen atau ventilasi mekanis. Penatalaksanaan di rumah ditujukan untuk mempertahankan PPOK stabil. Penalaksanaan di rumah meliputi:

a. Berhenti merokok

Faktor risiko yang paling penting dalam etiopatogenesis PPOK adalah merokok. Ada bukti kuat hubungan antara penurunan fungsi paru dan perilaku merokok. Meskipun merokok mempengaruhi sekitar $15 \%$ dari variabilitas fungsi paru. Data epidemiologis menunjukkan bahwa selain kebiasaan merokok, genetika menjadi salah satu faktor tersebut.

b. Penggunaan obat-obatan dengan tepat

Penggunaan obat disarankan menggunakan klasifikasi GOLD. Pemilihan obat obat dapat berupa handihaler, diskhaler, nebuhaler, turbuhaler atau breezhaler. Pasien PPOK biasanya menyerang usia lanjut, hal ini disebabkan karena koordinasi neurologis dan kekuatan otot mulai berkurang sehingga penggunaan DPI menjadi kurang efektif. Oleh sebab itu pada usia lanjut nebulizer digunakan hanya bila timbul eksaserbasi.

c. Terapi oksigen

Terapi dibedakan untuk PPOK derajat sedang dan berat. Pada PPOK derajat sedang, oksigen digunakan apabila muncul sesak yang disebabkan karena pertambahan aktivitas. Pada PPOK derajat berat, terapi oksigen di gunakan di rumah terus-menerus selama 15 jam pada saat beraktivitas juga pada waktu istirahat/tidur. Dosis oksigen tidak lebih dari 2 liter per menit. Jika saturasi masih di bawah $88 \%$ meskipun telah menggunakan venturi mask $28 \%$, dapat diganti dengan kanul hidung pada 2-6 1/menit atau simple mask $51 /$ menit dengan target saturasi 88-92\%. Pada pasien dengan hiperkapnia (PaCO2 0,6 kPa atau $45 \mathrm{~mm} \mathrm{Hg}$ ) dan asidosis $(\mathrm{pH}, 7,35$ atau $[\mathrm{H}+] 0,45 \mathrm{nmol} / \mathrm{l})$ dipertimbangkan penggunaan NIV, terutama jika asidosis telah berlangsung selama lebih dari 30 menit meskipun telah mendapatkan terapi yang tepat. ${ }^{6}$

d. Penggunaan ventilasi mekanik

Beberapa pasien PPOK dapat menggunakan ventilasi mekanik di rumah.

e. Rehabilitasi ${ }^{5}$

- Menyesuaikan aktivitas

- Latihan ekspektorasi (huff cough)

- Latihan ekstremitas atas dan otot bantu napas. Prioses rehabilitasi meningkatkan aktivitas fisik, toleransi latihan, dan penurunan dyspnea dan kelelahan. 
f. Evaluasi dan pemantauan

- Tanda eksaserbasi

- Efek samping obat

- Kecukupan dan efek samping penggunaan oksigen $^{5}$

2. Penatalaksanaan pada Eksaserbasi Akut

Eksaserbasi akut pada PPOK adalah adanya perburukan dibandingkan kondisi sebelumnya sehingga dapat mengubah metode terapi. Eksaserbasi dapat disebabkan oleh infeksi atau faktor lain seperti polusi udara, kelelahan, atau timbulnya komplikasi. ${ }^{5}$

Gejala eksaserbasi di antaranya adalah: 1) Sesak bertambah; 2) Produksi sputum meningkat, dan 3) Perubahan warna sputum (sputum menjadi purulen). Eksaserbasi akut menurut kriteria Anthonisen 1987 dibagi menjadi tiga: ${ }^{7}$

a. Tipe I (eksaserbasi berat), memiliki 3 gejala di atas.

b. Tipe II (eksaserbasi sedang), memiliki 2 gejala di atas.

c. Tipe III (eksaserbasi ringan), memiliki 1 gejala di atas ditambah infeksi saluran napas atas lebih dari 5 hari, demam tanpa sebab lain, peningkatan batuk, peningkatan mengi atau peningkatan frekuensi pernapasan $>20 \%$ dari nilai dasar, atau frekuensi nadi $>20 \%$ dari nilai dasar.

Penatalaksanaan eksaserbasi dibagi menjadi:

a. Eksaserbasi ringan: meningkatkan pemakaian bronkodilator (dapat dilakukan di rumah atau poliklinik).

b. Eksaserbasi sedang: menambahkan antibiotik atau kortikosteroid sistemik atau keduanya (dapat dilakukan di puskesmas, poliklinik, atau praktek dokter).

c. Eksaserbasi berat: perawatan di rumah sakit.

Penggunaan ventilasi saat eksaserbasi dapat digunakan ventilasi noninvasif (kanul hidung atau simple mask) atau invasif (Orotracheal tube atau trakeostomi). Stimulan pernapasan tidak dianjurkan untuk gagal napas akut. ${ }^{5}$

Eksaserbasi pada PPOK paling banyak disebabkan oleh infeksi trakeobronkial dan polusi udara. Namunl 1/3 penyebab dari eksaserbasi berat untuk saat ini masih belum dapat diidentifikasi termasuk penyebab lain yaitu adanya bakteri juga masih kontroversial. Penelitian terbaru pada bronkoskopi menunjukkan bahwa sekitar $50 \%$ dari pasien eksaserbasi terdapat bakteri dalam konsentrasi tinggi pada saluran napas bawah sehingga hal ini menunjukkan bukti adanya kolonisasi bakteri.. ${ }^{2}$

Tabel 1. Pengobatan berdasarkan kelompok PPOK (GOLD 2016) ${ }^{1}$

\begin{tabular}{|c|c|c|c|}
\hline $\begin{array}{c}\text { Kelompok } \\
\text { Pasien }\end{array}$ & Obat pilihan pertama & Obat pilihan alternatif & Teofilin \\
\hline A & $\begin{array}{l}\text { Antikolinergik kerja singkat, bila } \\
\text { perlu } \\
\text { atau } \\
\text { ß2 agonis kerja singkat bila perlu }\end{array}$ & $\begin{array}{l}\text { Antikolinergik kerja lama } \\
\text { atau } \\
\beta 2 \text { agonis kerja lama } \\
\text { atau } \\
\beta 2 \text { agonis kerja singkat dan } \\
\text { antikolinergik kerja singkat }\end{array}$ & $\begin{array}{l}\beta 2 \text { agonis kerja singkat dan/atau } \\
\text { Antikolinergik kerja singkat } \\
\text { Teofilin }\end{array}$ \\
\hline B & $\begin{array}{l}\text { Antikolinergik kerja lama } \\
\text { atau } \\
\beta 2 \text { agonis kerja lama }\end{array}$ & $\begin{array}{l}\text { Antikolinergik kerja lama dan } \beta 2 \text { agonis } \\
\text { kerja lama }\end{array}$ & $\begin{array}{l}\text { \$2 agonis kerja singkat dan/atau } \\
\text { Antikolinergik kerja singkat } \\
\text { Teofilin }\end{array}$ \\
\hline $\mathrm{C}$ & $\begin{array}{l}\text { Kortikosteroid inhalsi }+\beta 2 \text { agonis } \\
\text { kerja lama } \\
\text { Atau } \\
\text { Antikolinergik kerja lama }\end{array}$ & $\begin{array}{l}\text { Antikolinergik kerja lama dan } \beta 2 \text { agonis } \\
\text { kerja lama } \\
\text { atau } \\
\text { Antikolinergik kerja lama dan PDE4 } \\
\text { inhibitor } \\
\text { atau } \\
\beta 2 \text { agonis kerja lama dan PDE4 } \\
\text { inhibitor }\end{array}$ & $\begin{array}{l}\text { ß2 agonis kerja singkat dan/atau } \\
\text { Antikolinergik kerja singkat } \\
\text { Teofilin }\end{array}$ \\
\hline $\mathrm{D}$ & $\begin{array}{l}\text { Kortikosteroid inhalasi }+\beta 2 \\
\text { agonis kerja lama dan/atau } \\
\text { Antikolinergik kerja lama }\end{array}$ & $\begin{array}{l}\text { Kortikosteroid inhalasi }+\beta 2 \text { agonis kerja } \\
\text { lama dan kerja lama } \\
\text { atau } \\
\text { Kortikosteroid inhalasi }+\beta 2 \text { agonis kerja } \\
\text { lama dan PDE4 } \\
\text { atau } \\
\beta 2 \text { agonis kerja lama dan } \\
\text { Antikolinergik kerja lama } \\
\text { atau } \\
\text { Antikolinergik kerja lama dan PDE4 } \\
\text { inhibitor }\end{array}$ & $\begin{array}{l}\text { Carbocystein } \\
N \text {-acetylsistein } \\
\beta 2 \text { agonis kerja singkat dan/atau } \\
\text { Antikolinergik kerja singkat } \\
\text { Teofilin }\end{array}$ \\
\hline
\end{tabular}




\section{Perbandingan Terapi Kombinasi ICS/LABA - Terapi Tunggal pada PPOK}

Manfaat klinis pengobatan kombinasi extrafine beclometason diproprionat/formoterol fumarat dapat dilihat pada penelitian TORCH (Towards a Revolution in COPD Health), yaitu percobaan acak selama 3 tahun, lebih dari 6.000 pasien dengan PPOK moderat-berat dibandingkan dengan inhalasi flutikason propionat (FP) dan salmeterol (S) saja atau dalam kombinasi dengan plasebo. ${ }^{8}$ Sekitar $17,5 \%$ risiko kematian lebih rendah (pengurangan risiko absolut dari 2,6\%) pada terapi kombinasi dibandingkan dengan plasebo. Terapi ICS/LABA mengurangi angka kejadian eksaserbasi sedang/berat dibandingkan dengan plasebo dan terapi monokomponen. Selain itu, dengan pengobatan ICS/LABA, kerusakan fungsi paru terjadi lebih lambat dibandingkan dengan plasebo.

\section{Mekanisme Kerja Kortikosteroid dan Bronkodilator}

$\beta 2$ agonis dan kortikosteroid mempunyai target farmakologi yang berbeda dan interaksi sinergis, antara lain: ${ }^{9}$

a. ICS meningkatkan densitas $\beta 2$-adrenoreseptor di saluran udara, yang dapat mengimbangi reseptor down regulation, sehingga dapat mencegah intoleransi LABA.

b. LABA mendukung translokasi inti reseptor glukokortikoid sehingga meningkatkan mekanisme kerja ICS.

\section{Extrafine Particle ICS/LABA-Fine Particle ICS/LABA}

Terapi kombinasi obat kortikosteroid/long-acting 32-agonis (ICS/LABA) kombinasi extrafine beclometason dipropionat dan formoterol fumarat (BDP/FF) baru-baru ini disetujui di Eropa sebagai terapi pada PPOK. Pada PPOK, terjadi inflamasi saluran napas dan remodeling. Oleh karena itu, kemampuan formulasi extrafine dalam mencapai saluran nafas kecil yang sama baiknya pada saluran napas besar menjadi penting karena pengobatan dapat menjangkau proses inflamasi di seluruh bronchial tree. Pengaruh extrafine BDP/FF menunjukkan manfaat yang signifikan terhadap peningkatan fungsi paru dan pengurangan tingkat eksaserbasi, sehingga mendukung efek menguntungkan kombinasi ICS dan LABA pada pasien PPOK. Dalam suatu penelitian perbandingan head-to-head terhadap kombinasi ICS/LABA yang lain (fine particle) menunjukkan bahwa formulasi extrafine memberi manfaat klinis yang lebih baik, serta penggunaan dosis ICS yang lebih rendah. Pemberian extrafine BDP/FF menunjukkan perbaikan fungsi paru dan gejala sesak yang sebanding dengan ICS/LABA lainnya, dan onset kerjanya lebih cepat bila dibandingkan dengan kombinasi salmeterol/ICS. Extrafine particle yaitu; massa aerodinamis diameter $<2,0 \mu \mathrm{m}$, dengan formulasi komponen aktif BDP 100 ug dan FF 6 mg per inhalasi. Inflamasi saluran napas kecil adalah penanda penting pada PPOK. ${ }^{10}$ Formulasi extrafine memungkinkan efisiensi deposit paru, yang memungkinkan pengurangan sekitar setengah dosis aerosol BDP konvensional dan meminimalkan efek sistemik. BDP/FF 100/6 $\mu$ berlisensi untuk terapi PPOK dengan menggunakan MDI atau DPI. Banyak pasien memilih untuk menggunakan MDI, dan pilihan untuk menggunakan formulasi extrafine dengan MDI dengan atau tanpa spacer menawarkan pilihan pengobatan yang lebih baik untuk pasien PPOK. ${ }^{11}$

\section{Deposit Paru Endapan pada Extrafine BDP/FF ${ }^{12}$}

Kemampuan extrafine BDP/FF untuk mencapai pusat dan perifer deposit paru telah diteliti secara terbuka, dosis tunggal, parallel-group. Penelitian tersebut melibatkan 10 relawan sehat dan 8 pasien dengan PPOK stabil (FEV1 44\% dari prediksi). Pasien menghirup empat aktuasi dari radio labelled ${ }^{99 \mathrm{~m}} \mathrm{Tc}$ $\mathrm{BDP} / \mathrm{FF}$ dan dengan kamera pencitraan gamma diukur aktivitas di seluruh paru dan ekstra toraks, serta jumlah partikel yang dihembuskan. Deposit pada dua kelompok hampir sama yaitu 34\% dan 33\% dari dosis nominal pada sukarelawan sehat dan pasien PPOK. vJumlah obat yang dihembuskan kecil, berkisar 2,8-3,4\% dari dosis nominal, sehingga mengkonfirmasikan bahwa jumlah partikel extrafine yang dihembuskan jumlahnya minimal. DeBacker dkk. menggunakan multi-slice computed tomography (CT) scan dan Computational Fluid Dynamics untuk mengevaluasi efek dari formulasi $\mathrm{BDP} / \mathrm{FF}$ extrafine pada saluran napas pada pasien PPOK. Pemberian extrafine BDP/FF menyebabkan perbaikan signifikan pada saluran napas sekitar 4-6 jam, perbaikan saluran udara bagian bawah lebih besar dibandingkan dengan saluran udara bagian atas. Setelah 6 bulan pengobatan, hiperinflasi di tingkat lobar berkurang signifikan dibandingkan baseline. Perubahan ini terkait dengan pengurangan hiperinflasi yang diukur dengan kapasitas residual fungsional (FRC) dan peningkatan FEV1. Temuan ini menunjukkan kemampuan BDP/FF dalam meningkatkan fisiologi paru di saluran udara kecil.

\section{Keunggulan Extrafine Particle}

Papi dkk. menyebutkan beberapa keunggulan kombinasi extrafine BDP/formotrerol pada Gambar 2.

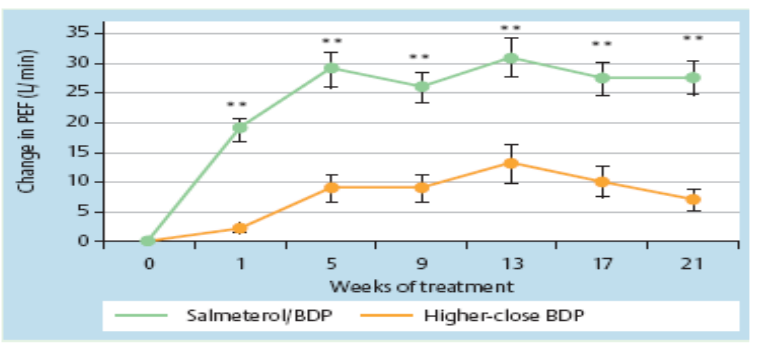

Gambar 2. Keunggulan terapi kombinasi LABA/ICS dalam perbaikan fungsi paru ${ }^{13}$ 


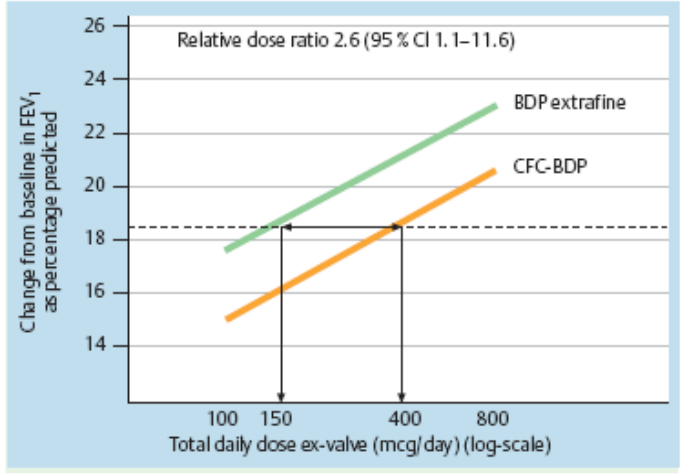

(A)

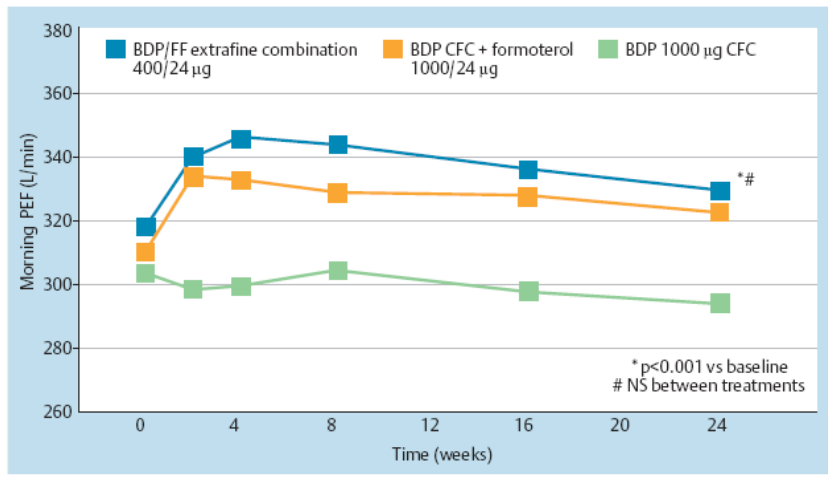

(B)

Gambar 3. A). Formulasi extrafine membutuhkan dosis kortikosteroid lebih rendah dibandingkan dengan formulasi non-extrafine BDP B). Hasil PEF pagi kombinasi extrafine BDP/FF lebih baik dibandingkan dengan BDP/FF maupun BDP tunggal $^{13}$

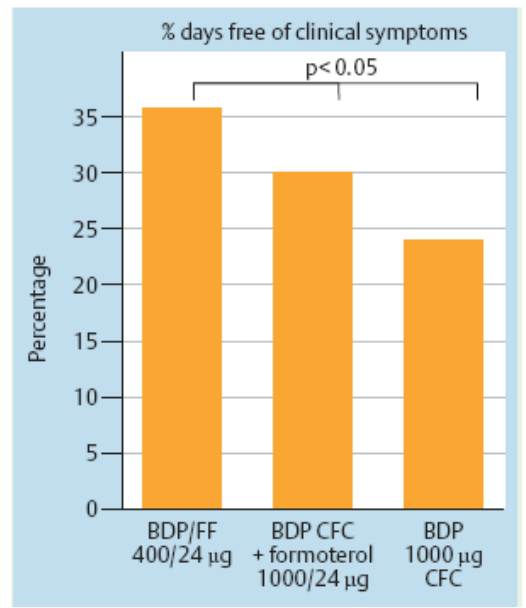

(A)

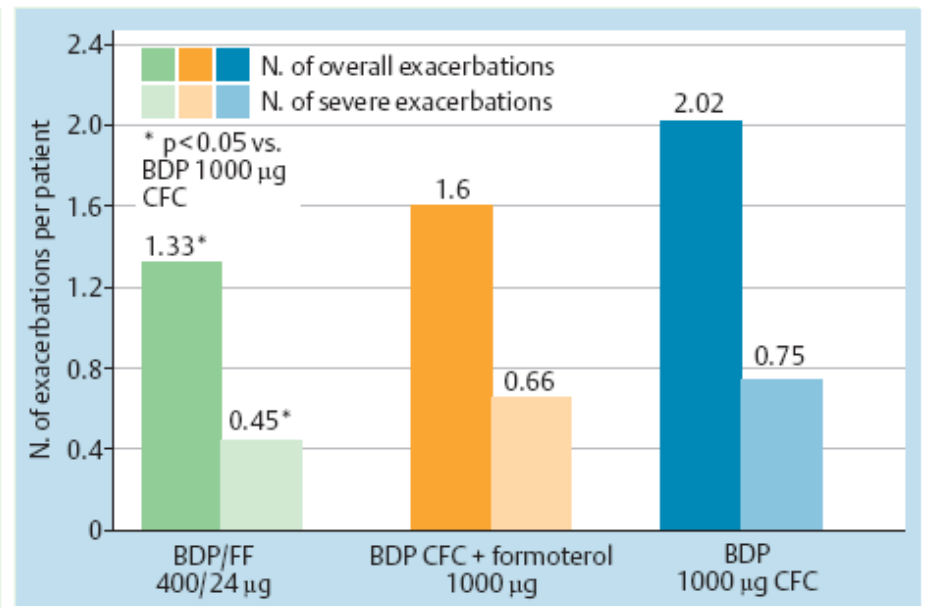

(B)

Gambar 4. A). Keluhan pasien lebih berkurang dengan extrafine BDP/FF dibandingkan dengan terapi BDP/FF konvensional maupun BDP tunggal B). Eksaserbasi PPOK lebih berkurang dengan extrafine BDP/FF dibandingkan dengan terapi $\mathrm{BDP} / \mathrm{FF}$ konvensional maupun BDP tunggal ${ }^{13}$

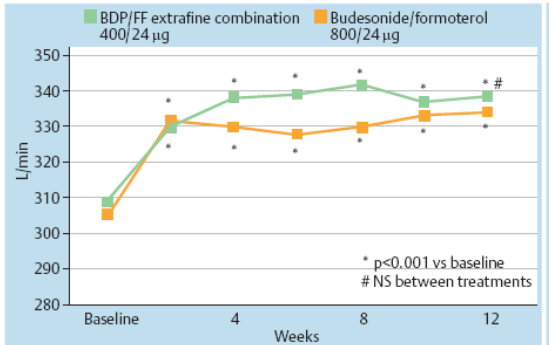

(A)

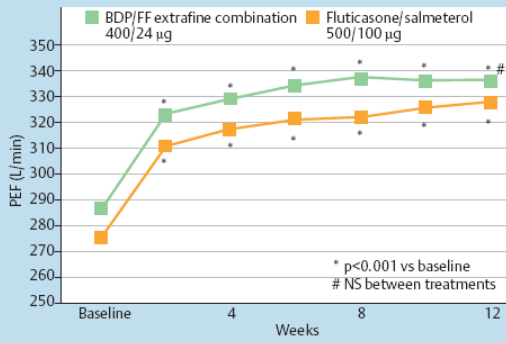

(B)

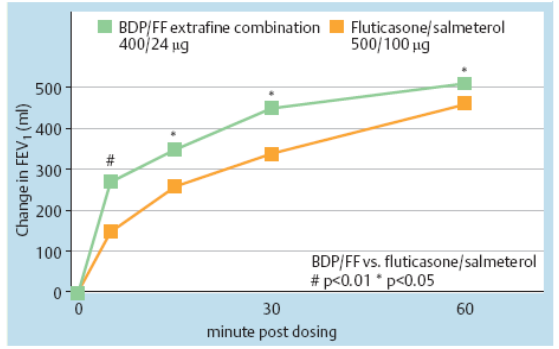

(C)

Gambar 5. A). Hasil PEF pagi lebih baik dengan dosis yang lebih rendah extrafine BDP/FF dibandingkan dengan terapi BDP/FF. B). Hasil PEF pagi extrafine BDP/FF lebih baik dibandingkan dengan terapi Fluticason/Salmeterol C). Efek bronkodilator obat kombinasi extrafine $\mathrm{BDP} / \mathrm{FF}$ onset lebih cepat bila dibandingkan dengan obat Fluticason/Salmeterol ${ }^{13}$

\section{Teknologi Formulasi Extrafine Beclometason}

Terapi kombinasi telah berkembang dalam beberapa tahun terakhir. Kombinasi terapi baru seperti Innovair ${ }^{\circledR}$ dikembangkan untuk memberikan terapi yang disesuaikan dengan kebutuhan pasien. Innovair ${ }^{\circledR}$ berisi kombinasi beklometason dipropionat (BDP), ICS dengan banyak manfaat, dan formoterol (F), LABA dengan onset bronkodilatasi cepat, dengan sedian inhaler yang berisi senyawa aktif extrafine. Inhalasi mikrosol mengandung $100 \mathrm{mg}$ extrafine beklometason dan $6 \mathrm{pg}$ formoterol. Dosis yang dianjurkan untuk pasien di atas 18 tahun adalah satu atau dua hisap dua kali sehari. Formulasi extrafine menunjukkan efek klinis yang sebanding dengan formulasi non-extrafine 
konvensional BDP, bahkan dengan 2,6 kali dosis yang lebih rendah. Dengan demikian, pajanan sistemik kortikosteroid berkurang, dan efek samping lebih rendah. Teknologi mikrosol adalah prototipe dari generasi baru propelan gas-driven MDI (Metered Dose Inhaler). Berbeda dengan MDI konvensional, kombinasi baru ini adalah BDP dan formoterol terlarut sepenuhnya. Keuntungan dari hal ini adalah bahwa aerosol dapat nebulized di partikel ekstra-halus (mikrosol) dibandingkan dengan suspensi inhaler atau DPI, dan dapat memberikan dosis konstan yang memungkinkan deposisi yang lebih baik pada saluran udara perifer. ${ }^{13}$

Beberapa tahun terakhir, peran saluran udara kecil (Diameter $<2 \mathrm{~mm}$ ) menjadi fokus perhatian dalam penelitian tentang asma dan penyakit paru obstruktif lainnya. Secara khusus, inflamasi dan proses remodelling tidak terbatas pada saluran pernapasan yang lebih besar seperti yang diduga sebelumnya, tetapi juga terjadi pada saluran udara kecil dan bronkiolus. Formulasi baru menggunakan teknologi yang dioptimalkan untuk pengiriman partikel halus, jumlah obat yang lebih besar untuk dapat mencapai saluran udara kecil dibandingkan dengan inhaler konvensional, sehingga dosis nominal BDP dapat dikurangi sekitar 2,5 kali dengan formulasi baru. Efikasi dan keamanan dari kombinasi tetap telah didokumentasikan dalam beberapa uji coba terkontrol secara acak. ${ }^{13}$

Tiga penelitian NCT00476099, FORWARD, dan FUTURE, menemukan bahwa Extrafine BDP/FF 100/6 ug dibandingkan budesonide/formoterol fumarat (BUD/FF) 200/6 lebih superior dalam memperbaiki fungsi paru (FEV1) dan dengan tingkat eksaserbasi lebih rendah. ${ }^{14}$ Selain itu, extrafine BDP/FF menyebabkan peningkatan yang signifikan secara statistik pada FEV1 dibandingkan dengan FF. Tingkat eksaserbasi dalam penelitian ini jauh lebih rendah (kurang dari setengah) dari eksaserbasi yang biasanya diamati dalam penelitianpenelitian PPOK yang khusus mempelajari efek ICS pada eksaserbasi. Pada penelitian ini, rata-rata FVC secara signifikan lebih tinggi dari baseline pada extrafine BDP/FF, tetapi tidak pada kelompok BUD/FF dan kelompok FF. Perubahan signifikan FVC mencerminkan perubahan volume paru yang berhubungan dengan perbaikan dalam fungsi saluran napas distal. ${ }^{15}$

Untuk kualitas hidup, St. George(SGRQ) menunjukkan perbaikan yang signifikan dalam semua kelompok perlakuan. Pada uji jalan 6 menit (6MWT) didapatkan 41,1 meter pada extrafine BDP/FF, 35,4 meter pada kelompok BUD/FF dan 35,2 meter pada kelompok FF. Perbaikan 6MWT setelah pengobatan

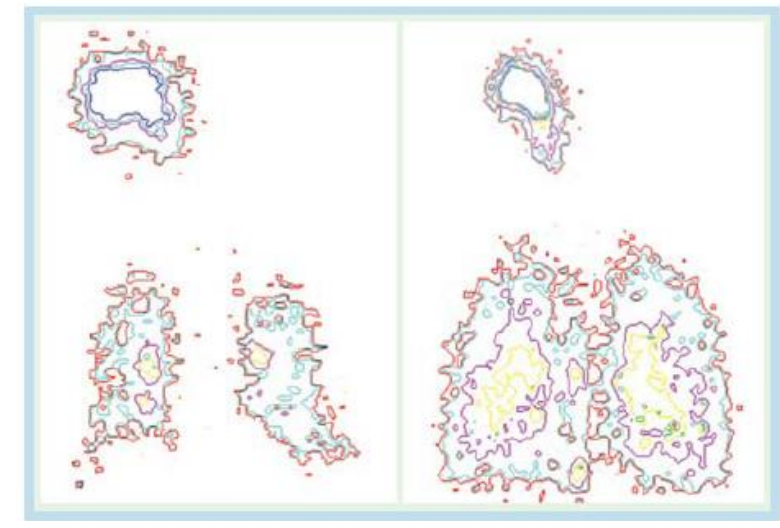

Gambar 6. Deposit obat extrafine pada saluran nafas kecil lebih baik dibanding dengan obat non-extrafine. ${ }^{13}$

$\mathrm{BDP} / \mathrm{FF}$ dapat terkait dengan perbaikan pada air trapping. Risiko utama pencetus eksaserbasi PPOK adalah infeksi virus, seperti influenza, dan infeksi saluran pernapasan atas. Hal ini bervariasi antar musim, antara tahun yang berbeda, dan antar negara. Extrafine $\mathrm{BDP} / \mathrm{FF}$ lebih unggul dibanding extrafine $\mathrm{FF}$ dalam mencegah eksaserbasi tahunan; ada penurunan $28 \%$ eksaserbasi sedang sampai berat dengan extrafine BDP/FF dibandingkan dengan FF. Selain itu, analisis subkelompok, stratifikasi pasien dengan menggunakan tiotropium, menunjukkan extrafine BDP/FF lebih unggul dibandingkan dengan FF untuk mengurangi eksaserbasi, baik pada pengguna tiotropium dan nontiotropium. Extrafine BDP/FF juga lebih unggul daripada FF untuk perubahan pra-dosis FEV1 pagi dari awal sampai minggu ke-12. ${ }^{16}$

\section{Extrafine BDP/FF dengan Triple Terapi atau Extrafine FF}

Keunggulan extrafine $\mathrm{BDP} / \mathrm{FF}$ vs extrafine $\mathrm{FF}$ dalam mengurangi eksaserbasi pada pengguna tiotropium adalah aspek baru dalam penelitian PPOK. Pada penelitan FORWARD, pengguna tiotropium memberikan informasi yang berguna, yaitu perbandingan triple terapi (ICS+LABA+LAMA) yang dibandingkan dengan terapi bronkodilator ganda (LABA+LAMA) pada eksaserbasi. Namun data yang didapatkan masih sedikit karena bila digunakan ICS/LABA, penggunaan LAMA dihentikan. Penurunan eksaserbasi lebih besar pada extrafine BDP/FF dibandingkan dengan FF pada pasien PPOK berat. ICS/LABA dapat digunakan pada pasien dengan lebih dari 2 eksaserbasi pada tahun sebelumnya. Extrafine BDP/FF juga efektif pada pasien dengan FEV1 50$70 \% .^{17}$

Pada penelitian FORWARD, terdapat perdebatan mengenai seberapa banyak efek yang diamati dalam uji klinis akan memprediksi manfaat secara real-life. 
Tabel 2. Risiko pneumonia pada penggunaan kombinasi ICS/LABA dan LABA ${ }^{17}$

\begin{tabular}{|c|c|c|c|c|}
\hline \multirow[t]{2}{*}{ Study reference } & \multirow[t]{2}{*}{ Drugs and total daily dose $(\mu g)$} & \multirow[t]{2}{*}{ Study duration } & \multicolumn{2}{|c|}{$\%$ of patients with pneumonia } \\
\hline & & & $K S / L A B A$ & $\angle A B A$ \\
\hline Calverley et $a l^{12}$ & FP/S $1000 / 100$ versus $S 100$ & 3 years & 19.6 & 13.3 \\
\hline Kardos et al. ${ }^{45}$ & FP/S $1000 / 100$ versus $S 100$ & 44 weeks & 4.5 & 1.4 \\
\hline Calverley et $a l^{3}$ & BUD/FF $640 / 18$ versus FF 18 & 12 months & 3.1 & 2.7 \\
\hline Ferguson et $a l^{4}$ & FP/S $500 / 100$ versus $S 100$ & 12 months & 7.0 & 4.0 \\
\hline Rennard et al. ${ }^{7}$ & BUD/FF $320 / 9$ versus FF 9 & 12 months & 3.0 & 3.4 \\
\hline Rennard et al. ${ }^{7}$ & BUD/FF $160 / 9$ versus FF 9 & 12 months & 3.0 & 3.4 \\
\hline Anzueto et $a l^{46}$ & $\mathrm{FP} / \mathrm{S} 500 / 100$ versus $S 100$ & 52 weeks & 6.6 & 2.5 \\
\hline Carlverley et $a l^{20}$ & BDP/FF $400 / 24$ versus FF 24 & 48 weeks & 2.1 & 0.4 \\
\hline Carlverley et $a l^{20}$ & BUD/FF $800 / 24$ versus FF 24 & 48 weeks & 2.9 & 0.4 \\
\hline Sharafkhaneh et al. ${ }^{44}$ & BUD/FF $320 / 9$ versus FF 9 & 12 months & 6.4 & 2.7 \\
\hline Sharafkhaneh et al. ${ }^{44}$ & BUD/FF $160 / 9$ versus FF 9 & 12 months & 4.7 & 2.7 \\
\hline Dransfield et al. ${ }^{6}$ & FF/Nil $100 / 25$ versus Vil 25 & 52 weeks & 6.3 & 3.3 \\
\hline Wedzicha et al. ${ }^{28}$ & BDP/FF $400 / 24$ versus FF 24 & 48 weeks & 3.8 & 1.8 \\
\hline
\end{tabular}

Misalnya, kriteria inklusi uji klinis PPOK sering mengecualikan pasien dengan dan/atau penyakit gejala lebih parah dengan withdrawal obat inhalasi; pada penelitian ini pasien yang mengalami gejala ICS withdrawal dimasukkan dalam data, meskipun ada pengecualian pasien dengan komorbiditas signifikan seperti penyakit jantung. ${ }^{18}$

\section{Eosinofil Darah dan Tingkat Eksaserbasi ${ }^{19}$}

Jumlah eosinofil darah adalah biomarker penting untuk menilai respons terapi ICS pasien PPOK. Penurunan tingkat eksaserbasi dengan BDP/FFdibandingkan dengan FF berkisar antara 22\% pada pasien dalam kuartil terendah dan $46 \%$ pada pasien di kuartil tertinggi. Secara keseluruhan, tingkat eksaserbasi sebanding dengan jumlah eosinofil pada pasien yang menerima $\mathrm{BDP} / \mathrm{FF}$, sedangkan pola peningkatan tingkat eksaserbasi sebanding dengan meningkatnya jumlah eosinofil pada pasien yang diobati dengan FF saja. Hal ini menunjukkan efek pengobatan BDP/FF signifikan pada pasien dengan jumlah eosinofil darah yang tinggi.

Eosinofil darah $>2 \%$ disarankan sebagai ambang batas untuk mengklasifikasikan pasien yang memiliki fenotip PPOK eosinofilik. Manfaat BDP/FF lebih signifikan dibanding FF pada kedua kelompok, terutama pada pasien dengan eosinofil $>2 \%(34 \%)$ dibandingkan dengan eosinofil $<2 \%$. Bila menggunakan nilai cutoff 280 sel per $\mathrm{ml}$ (kuartil atas pada penelitian FORWARD), manfaat yang lebih besar (pengurangan $46 \%$ pada eksaserbasi) pada pasien dengan eosinofil yang lebih tinggi (280 sel per $\mathrm{ml}$ ) dan masih diperoleh efek yang signifikan (24\%) pada pasien dengan jumlah eosinofil di bawah threshold. Namun demikian, efek
ICS meningkat pada jumlah eosinofil lebih tinggi, karena eksaserbasi tidak efektif jika diobati dengan bronkodilator saja serta memberikan panduan lebih lanjut cutoff eosinofil darah yang dapat digunakan di praktek klinik.

\section{Extrafine BDP/FF dengan FP/S}

Pada penelitian FUTURE dilakukan secara multisenter selama 12 minggu, multinasional, acak, double-blind, yang membandingkan extrafine $\mathrm{BDP} / \mathrm{FF}$ 100/6 ug $(\mathrm{n}=211)$ dengan FP/Salmeterol (Seretide, Accuhaler GlaxoSmithKline, Middlesex, UK, 500/50 ug; $\mathrm{n}=208$ ) pada pasien PPOK sedang-berat. Tujuan dari penelitian ini adalah untuk menunjukkan superioritas extrafine BDP/FF dibandingkan FP/S, dalam hal fungsi paru (FEV1). Peningkatan FEV1 lebih besar pada extrafine BDP/FF dibandingkan dengan FP/S. Penggunaan ICS dapat menyebabkan efek samping seperti osteoporosis dan pneumonia. Pemberian dosis ICS lebih rendah pada BDP/ FF, dibandingkan dosis tinggi ICS pada FP/S yang mempunyai hasil yang sama pada perbaikan gejala sesak dan FEV1. Pemberian dosis rendah ICS menjadi penting untuk menghindari efek samping ICS dalam jangka panjang. Potensi obat extrafine BDP/FF dibanding FP/S memberi efek segera setelah pemberian dan efeknya menetap selama pengobatan jangka panjang. Hal ini disebabkan oleh onset formoterol yang lebih cepat dibandingkan dengan salmeterol. ${ }^{20}$

\section{Efek Samping}

Penelitian NCT00476099 dan penelitian MAJU adalah penelitian jangka panjang yang memberikan informasi yang relevan tentang efek samping. Dalam 
penelitian NCT00476099, kejadian efek samping serupa antar perawatan: $42,8 \%$ dari pasien dalam kelompok extrafine BDP/FF, 40,9\% kelompok FF/BUD dan 44,1\% pada kelompok $\mathrm{FF}$, penghentian dilaporkan hanya 9 $(3,8 \%)$ extrafine BDP/FF, $6(2,5 \%)$ FF/BUD dan 5 $(2,1 \%)$ pasien FF. ${ }^{21}$

Pneumonia telah diidentifikasi sebagai risiko untuk pasien PPOK yang mendapatkan terapi kombinasi ICS/LABA. Keseluruhan kejadiannya rendah, yaitu sekitar $<10 \%$, dan risiko tersebut harus ditafsirkan secara komprehensif terhadap manfaat dalam mengurangi eksaserbasi dan rawat inap yang mengancam jiwa. Hal ini juga harus dicatat, bahwa meningkatknya risiko terjadinya pneumonia pada pasien dengan terapi ICSLABA dibandingkan dengan yang monoterapi tidak terkait dengan peningkatan kejadian kematian. Dalam penelitian NCT00476099, pneumonia dilaporkan terjadi hanya pada $2,1 \%$ pasien kelompok extrafine $\mathrm{BDP} / \mathrm{FF}$, $2,9 \%$ pasien dengan terapi BUD/FF, dan 0,4\% pasien pada terapi FF. ${ }^{21}$

\section{RINGKASAN}

Extrafine $\mathrm{BDP} / \mathrm{FF}$ adalah satu-satunya ICS/LABA yang disetujui untuk digunakan pada pasien PPOK baik sebagai MDI dan DPI. Hal ini memungkinkan perawatan kesehatan profesional untuk memilih inhaler yang paling tepat berdasarkan kebutuhan pasien tertentu. Formulasi extrafine memungkinkan obat dapat mencapai saluran udara besar dan kecil dengan lebih baik, dan memungkinkan manfaat klinis yang akan dicapai dengan dosis ICS yang lebih rendah dibandingkan dengan fine-particle kombinasi ICS/LABA. Pemberian dosis rendah ICS menjadi penting untuk menghindari efek samping ICS dalam jangka panjang. Manfaat lebih dapat diperoleh dengan pemberian terapi extrafine BDP/FF dibanding FF dalam hal fungsi paru dan risiko eksaserbasi.

\section{DAFTAR PUSTAKA}

1. Indonesia PDP. Pedoman Diagnosis \& Penatalaksanaan Penyakit Paru Obstruktif Kronik (PPOK) di Indonesia. Jakarta, http://klikpdpi.com/index.php?mod=content\&sel= 93 (2016).

2. Vogelmeier CF, Criner GJ, Martinez FJ, et al. Global Strategy for the Diagnosis, Management, and Prevention of Chronic Obstructive Lung Disease 2017 Report. GOLD Executive Summary. Am J Respir Crit Care Med 2017; 195: 557-582.

3. Calverley P, Pauwels R, Vestbo J, et al. Combined salmeterol and fluticasone in the treatment of chronic obstructive pulmonary disease: a randomised controlled trial. Lancet (London, England) 2003; 361: 449-456.

4. Seifart C, Plagens A. Genetics of chronic obstructive pulmonary disease. Int $J$ Chron Obstruct Pulmon Dis 2007; 2: 541-550.

5. Vestbo J, Hurd SS, Agustí AG, et al. Global strategy for the diagnosis, management, and prevention of chronic obstructive pulmonary disease: GOLD executive summary. Am J Respir Crit Care Med 2013; 187: $347-$ 365.

6. O'Driscoll BR, Howard LS, Davison AG. BTS guideline for emergency oxygen use in adult patients. Thorax 2008; 63 Suppl 6: vi1-68.

7. Senior RM, Anthonisen NR. Chronic obstructive pulmonary disease (COPD). Am J Respir Crit Care Med 1998; 157: S139-47.

8. Haque R, Hakim A, Moodley T, et al. Inhaled long-acting $\beta 2$ agonists enhance glucocorticoid receptor nuclear translocation and efficacy in sputum macrophages in COPD. J Allergy Clin Immunol 2013; 132: 1166-1173.

9. Aziz I, Lipworth BJ. A bolus of inhaled budesonide rapidly reverses airway subsensitivity and beta2adrenoceptor down-regulation after regular inhaled formoterol. Chest 1999; 115: 623-628.

10. Hogg JC, Chu F, Utokaparch S, et al. The nature of smallairway obstruction in chronic obstructive pulmonary disease. N Engl J Med 2004; 350: 2645-2653.

11.Dhillon S, Keating GM. Beclometasone dipropionate/formoterol: in an HFA-propelled pressurised metered-dose inhaler. Drugs 2006; 66: 1475.

12. De Backer W, Devolder A, Poli G, et al. Lung deposition of BDP/formoterol HFA pMDI in healthy volunteers, asthmatic, and COPD patients. J Aerosol Med Pulm Drug Deliv 2010; 23: 137-148.

13. Papi A. Inhaled BDP/formoterol extra-fine combination. Evidence and future perspectives. Pneumologie 2009; 63 Suppl 2: S102-6.

14. Vijayasaratha K, Stockley RA. Reported and unreported exacerbations of COPD: analysis by diary cards. Chest 2008; 133: 34-41.

15. De Backer J, Vos W, Vinchurkar S, et al. The effects of extrafine beclometasone/formoterol (BDP/F) on lung function, dyspnea, hyperinflation, and airway geometry in COPD patients: novel insight using functional respiratory imaging. J Aerosol Med Pulm Drug Deliv 2015; 28: 8899.

16. Control EC for DP and. Surveillance reports and disease data on seasonal influenza, https://www.ecdc.europa.eu/en/seasonalinfluenza/surveillance-reports-and-disease-data.

17. Neyt M, Devriese S, Thiry N, et al. Tiotropium's costeffectiveness for the treatment of COPD: a cost-utility analysis under real-world conditions. BMC Pulm Med 2010; 10: 47.

18. Miravitlles M, Ferrer M, Pont A, et al. Effect of exacerbations on quality of life in patients with chronic obstructive pulmonary disease: a 2 year follow up study. Thorax 2004; 59: 387-395.

19. Cazzola M, MacNee W, Martinez FJ, et al. Outcomes for COPD pharmacological trials: from lung function to biomarkers. Eur Respir J 2008; 31: 416-469.

20.Singh D, Nicolini G, Bindi E, et al. Extrafine Beclomethasone/formoterol compared to Fluticasone/salmeterol Combination Therapy in COPD. BMC Pulm Med 2014; 14: 43. 
21. Kew KM, Seniukovich A. Inhaled steroids and risk of pneumonia for chronic obstructive pulmonary disease. Cochrane database Syst Rev 2014; CD010115. 